\title{
Drought-tolerance of an invasive alien tree, Acacia mearnsii and two native competitors in fynbos riparian ecotones
}

\author{
Casparus J. Crous · Shayne M. Jacobs • \\ Karen J. Esler
}

Received: 17 August 2010/ Accepted: 9 September 2011

(C) Springer Science+Business Media B.V. 2011

\begin{abstract}
Invasive alien plants (IAPs) have successfully invaded many riparian zones in South Africa, especially Australian Acacia spp. which are prevalent along riverbanks in the south-western Cape of South Africa. This Mediterranean-type climate region is predicted to endure severe future water shortages under likely scenarios of increased population growth and climate change, and IAPs aggravate this problem due to their profligate water use. Acacia mearnsii competes aggressively with native species, however, it remains unclear what physiological advantage the species has over co-occurring native species under the predicted reduced streamflow scenarios. A mechanistic approach was used to investigate how key native fynbos riparian woody tree species compare in vulnerability to drought-induced cavitation against A. mearnsii by comparing findings from three Mediterranean-type fynbos river systems that differ in streamflow. A. mearnsii showed lower water potential at $50 \%$ hydraulic conductivity loss $\left(\mathrm{P}_{50}\right.$ values $)$ compared to native species at certain sites, an indication of drought-tolerance. This suggests it is likely to
\end{abstract}

C. J. Crous $(\bowtie) \cdot$ S. M. Jacobs · K. J. Esler

Department of Conservation Ecology and Entomology,

Stellenbosch University, Private Bag X1, Matieland 7602,

South Africa

e-mail: casperc@sun.ac.za

C. J. Crous · K. J. Esler

Centre for Invasion Biology, Stellenbosch University,

Private Bag X1, Matieland 7602, South Africa persist under future drier conditions and it therefore remains a top priority for control. The native Brabejum stellatifolium had consistently higher water potentials across all sites than the other studied species, and is a potentially valuable species for restoration of south-western Cape riparian zones. Consistency in the shapes of species vulnerability curves across sites illustrated a species-specific hydraulic response to different water availability, strengthening the argument that this approach to distinguish site-level drought-tolerance between trees is a practical technique, with great application in understanding future geographic distribution under climate change, and potential for use in restoration research. Additionally, streamflow was an inaccurate predictor of species drought-tolerance along these riparian systems.

Keywords Invasive alien plant - Water potential . Carbon isotope $\cdot$ Restoration $\cdot$ Streamflow $\cdot$ Xylem cavitation

\section{Introduction}

Freshwater in South Africa is widely recognised as a dwindling resource that will severely inhibit future socio-economic growth (Davies and Day 1998; Walmsley et al. 1999). Global climate change could aggravate the already limited water situation (Schulze 
et al. 2001; Meadows 2006) and endanger plant and animal species associated with rivers and riparian wetlands. Climate change predictions indicate that Mediterranean-type ecosystem rivers in the southwestern Cape face declining runoff (Steynor et al. 2009) and may lose between 14 and 32\% of their total streamflow due to a combination of declining runoff and water extraction from urban areas (New 2002). These hydrological systems are therefore highly vulnerable and there is justifiable concern for the ecological stability of river systems and the subsequent matters pertaining to water resource management. Invasions by woody alien plant species aggravate this problem due to the propensity of these plants to use large amounts of water.

Invasive alien plants (IAPs) are a global concern as they have an enormous impact on biodiversity, water resources and ecosystem services. The loss in water resources associated with high evapotranspiration rates from IAPs in South Africa has especially caused concern. The effects that invasive alien timber plantations and escapees from plantations have on water resources, particularly streamflow quantities has received much attention (Bosch and Hewlett 1982; Le Maitre et al. 1996, 2002; Scott et al. 1998; Dye and Jarmain 2004). Results vary but generally show a significant reduction in streamflow quantity in catchments planted to exotic plantations and in riparian zones converted to stands of IAPs. Additionally, some Acacia species have been shown to exhibit high resistance to drought-induced xylem cavitation (Maherali et al. 2004), and thus, should they be introduced outside their native ranges, they have the potential to outcompete native species and persist under drier conditions predicted for many parts of South Africa. It is not known whether this apparent advantage holds for woody IAPs in South Africa, and more specifically for Acacia mearnsii in the southwestern Cape. This is in addition to a suite of other advantages Acacia species have e.g. increased photosynthetic capacity (Kraaij and Cramer 1999; as reviewed in Morris et al. 2011). Investigating whether A. mearnsii is more drought tolerant than native species and whether this holds for rivers of different sizes can aid strategic planning and expenditure and ultimately more effective conservation management and ecosystem restoration, necessary after clearing of invasions takes place (Richardson and Van Wilgen 2004). As an example, this information would enable us to predict and prioritize areas where the IAP holds the physiological advantage. A recent study showing differences in vulnerability of native fynbos riparian vegetation has shown the value of this type of research (Swift et al. 2008).

In order to understand the physiological basis for plant adaptations to drought, Sperry et al. (1988) developed a technique that measures the level of xylem cavitation in plant stems. This method essentially relates xylem water potentials to loss in xylem hydraulic conductivity due to chronic water deficit when excised stems are allowed to dehydrate (Tyree and Sperry 1988). The end result is a vulnerability curve, which is useful to evaluate different species' vulnerability to cavitation by comparing xylem water potential against the point where $50 \%$ hydraulic conductivity is lost ( $50 \%$ of xylem cavitated), referred to as the $\mathrm{P}_{50}$ value (e.g. Hacke et al. 2000; Wheeler et al. 2005; Maherali et al. 2006; Swift et al. 2008). The study of vulnerability to cavitation has been applied to many different ecological questions, e.g. determining the variation in drought-tolerance between subspecies (Kolb and Sperry 1999); determining the underlying mechanism of tree distribution (Pockman and Sperry 2000); variance in drought resistance between important agricultural cultivars (Wikberg and Ögren 2004; Cochard et al. 2008); variance in drought resistance between native and alien species (Pratt and Black 2006); and possible impacts of climate change on species survival (Martínez-Vilalta et al. 2002). It has also proved to be an insightful approach in restoration ecology (Swift et al. 2008). Swift et al. (2008) showed how key riparian species in the South African fynbos region had differences in their vulnerability to drought-induced cavitation, with the least vulnerable individuals observed at low streamflow sites. This implies that streamflow may be a valuable proxy for indicating plant water availability although this is not always the correct assumption for riparian species (see e.g. Dawson and Ehleringer 1991). Further exploration of the hypothesis put forward by Swift et al. (2008) that streamflow volume is strongly linked to droughttolerance, could provide valuable information for restoration managers as a robust tool to predict sites where plants might experience more intense droughtstress.

In addition, drought-tolerance must be seen in conjunction with leaf-level regulation of water as different plants may adopt different ecological 
strategies to cope under dry conditions (Lambers et al. 1998). A recent framework by McDowell et al. (2008) emphasized the two main strategies that plants may use to cope with declining water availability. On the one hand, some plants may continue carbon assimilation by keeping stomata open under low water potentials (anisohydry). On the other hand, species close their stomata to prevent excessive loss of water under dry conditions, in so doing relieving cavitation pressure on plants (isohydry). These strategies may manifest in the measured $\delta^{13} \mathrm{C}$ values as indicator of water-use efficiency. Seibt et al. (2008) described the potential of $\delta^{13} \mathrm{C}$ in understanding possible effects of global warming on WUE, and subsequent species survival strategies. Therefore, at the leaf level, we investigated $\delta^{13} \mathrm{C}$ as indicator of water-use efficiency (WUE) where higher $\delta^{13} \mathrm{C}$ values indicate higher WUE (Farquhar et al. 1982). It has been suggested that rapid alien invasion, specifically in fynbos, could be attributed to factors such as plant WUE (Kraaij and Cramer 1999; Morris et al. 2011). Therefore understanding if invasive species outcompete native species at the whole plant level (less vulnerable to cavitation) and at the leaf level (better WUE) could prove highly insightful.

Our study addressed the following key questions: (1) In a water-limited scenario, how do key native fynbos riparian woody tree species compare in vulnerability to drought-induced cavitation, xylem water potentials and WUE against the woody tree invasive A. mearnsii? (2) Which of the studied key native species will be most suited for restoration? (3) Could streamflow be a robust screening tool when predicting which sites would be most vulnerable to cavitation, as one would expect individuals at high flow sites to be less drought-tolerant, than those in low flow areas (sensu Swift et al. 2008)? We investigated these questions by comparing findings from three Mediterranean-type fynbos river systems that differ in streamflow, ranging from low to high flow.

\section{Methods}

Description of species and study sites

The native, predominantly riparian species, Brabejum stellatifolium (L.) (Proteaceae) and Metrosideros angustifolia (L.) (Myrtaceae) (Coates-Palgrave 2002; Reinecke and King 2007), were selected to study as these evergreen trees, which are the only indigenous species of their genus in South Africa, are key species in south-western Cape Mediterranean-type riparian systems (Prins et al. 2004; Galatowitsch and Richardson 2005). Native species physiology was contrasted with the evergreen invasive woody species $A$. mearnsii DeWild (L.) (Fabaceae), which poses a major threat to functioning of riparian zones in the south-western Cape (Dye and Jarmain 2004). Although A. mearnsii can also grow in upland areas under low water availability (for example, it is a forestry tree in some parts of South Africa), it is highly competitive in riparian areas where it characteristically uses large amounts of water (Dye et al. 2001). Research has shown that intra-specific variation in drought-tolerance across wet and dry habitats does exist, where one species that showed high drought-tolerance in the dry areas did not show the same degree of drought-tolerance in wet areas (Mencuccini and Comstock 1997; Sparks and Black 1999). We cannot therefore assume that a species will always outcompete the co-occurring riparian species in terms of drought-tolerance simply because it can also grow in dryland areas (Pratt and Black 2006), as functional convergence in traits has been observed in several ecosystems (Meinzer 2003).

The study sites were the Eerste River at Jonkershoek (33⒌ $57.621^{\prime} \mathrm{S}, 1^{\circ} 55.037^{\prime} \mathrm{E}$; $200 \mathrm{~m}$ a.s.l.), Wit River at Bainskloof $\left(33^{\circ} 34.217^{\prime} \mathrm{S}, 1^{\circ} 08.452^{\prime} \mathrm{E} ; 279 \mathrm{~m}\right.$ a.s.l.) and Molenaars River at DuToitskloof $\left(33^{\circ} 41.778^{\prime} \mathrm{S}\right.$, $19^{\circ} 13.263^{\prime} \mathrm{E} ; 297 \mathrm{~m}$ a.s.1.), all of which are scrub type riparian zones in the Western Cape of South Africa. Site selection was based on the following criteria: the presence of the selected suite of two native and one invasive species; the river system is invaded and no restoration/clearing has occurred and sites differ in streamflow quantity-i.e. ranging from high to low flow. Jonkershoek (JNK) represents the low flow site, Bainskloof (BSK) the intermediate flow site and DuToitskloof (DTK) the high flow site (Fig. 1).

In Table 1 we summarise the geomorphological characteristics of the rivers. Jonkershoek and Bainskloof are draining catchments with predominantly sandstone geology, while at DuToitskloof, sandstone is mixed with igneous rocks. The Bainskloof site is situated in the Mountain Stream Transitional zone, while the two other sites are in the Upper Foothills, which have a lower gradient. The sampled trees also occupy different elevations above and distances away from the active channel (during low flow conditions). 


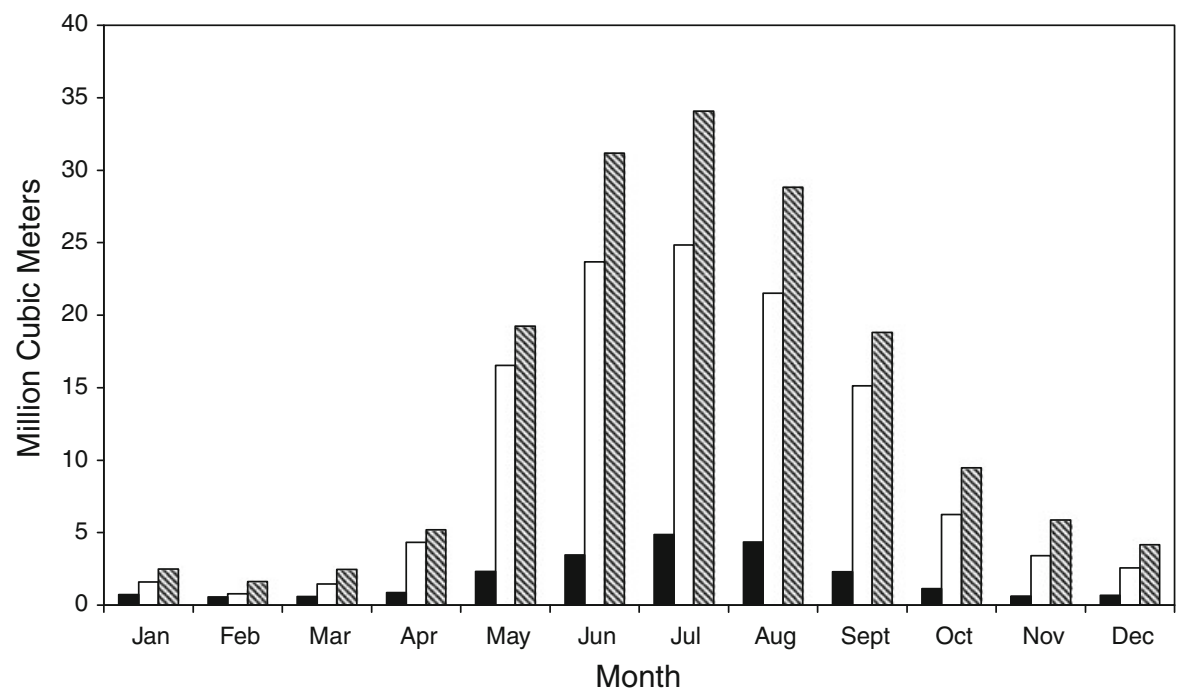

Fig. 1 Mean monthly streamflow at three study sites representing low, intermediate and high streamflow regimes respectively (from 1970 to 2008). Jonkershoek (black bars), Bainskloof (open bars) and DuToitskloof (cross-hatched bars).
Data for Jonkershoek were obtained from the CSIR, and that of DuToitskloof and Bainskloof from Department of Water Affairs and Forestry (now Department of Water Affairs)

Table 1 Site-specific information on each of the sites, including the major features of the rivers and the specific river reaches where the sites are situated, as well as pertinent information on the locality of the sample trees in relation to the stream

\begin{tabular}{|c|c|c|c|}
\hline & Jonkershoek & Bainskloof & DuToitskloof \\
\hline River & Eerste & Wit & Molenaars \\
\hline River type (Naiman and Decamps 1997) & Perennial & Perennial & Perennial \\
\hline Geology & Sandstone & Sandstone & Sandstone and Igneous \\
\hline $\begin{array}{l}\text { Characteristic channel features (according } \\
\text { to King and Schael 2001) }\end{array}$ & $\begin{array}{l}\text { Moderately steep, cobble-bed } \\
\text { and mixed bedrock-cobble } \\
\text { bed channel. }\end{array}$ & $\begin{array}{l}\text { Moderately steep, } \\
\text { dominated by } \\
\text { bedrock or boulder }\end{array}$ & $\begin{array}{l}\text { Moderately steep, cobble- } \\
\text { bed and mixed bedrock- } \\
\text { cobble bed channel }\end{array}$ \\
\hline $\begin{array}{l}\text { Longitudinal Zone (according to King and } \\
\text { Schael 2001) }\end{array}$ & Upper Foothills & $\begin{array}{l}\text { Mountain Stream } \\
\text { Transitional Zone }\end{array}$ & Upper Foothills \\
\hline $\begin{array}{l}\text { Range in the distance of sample trees from } \\
\text { streams edge during low flow conditions }\end{array}$ & $<2 \mathrm{~m}$ & $2-10 \mathrm{~m}$ & $<5 \mathrm{~m}$ \\
\hline $\begin{array}{l}\text { Zonation pattern where sample trees were } \\
\text { located (Boucher and Tlale 1999; Sieben } \\
\text { and Reinecke 2008) }\end{array}$ & Dry bank & Dry bank & Dry bank \\
\hline $\begin{array}{l}\text { Elevation above stream during low flow } \\
\text { conditions }\end{array}$ & $<1 \mathrm{~m}$ & $1-3 \mathrm{~m}$ & $<1 \mathrm{~m}$ \\
\hline
\end{tabular}

In addition, visually, the highest cover of alien species (including Acacia, Populus and Quercus spp.) was found at Jonkershoek and at DuToitskloof (predominantly Acacia), though a recent fire at the latter site considerably reduced the green biomass. At Bainskloof some clearing occurred on the northern bank, and none on the sampled southern bank (Reinecke and King 2007).

\section{Vulnerability to cavitation}

Vulnerability to cavitation was measured using the dehydration method (bench drying method) (Sperry et al. 1988; Pockman and Sperry 2000; Swift et al. 2008). By determining xylem hydraulic conductivity loss due to cavitation, plotted against xylem water potential, drought vulnerability curves were obtained 
(Tyree and Sperry 1988). Sampling was conducted during the driest months to capture the period of highest drought stress (lowest water potential) (December 2008-February 2009). Five individuals per species were sampled. Seven branches from each individual were cut at pre-dawn when the first sample was also bagged (to equilibrate transpiration through the plant) for the $0 \mathrm{~h}$ measurement. The remaining branches were then transported to the laboratory and allowed to dehydrate for $1,2,4,6,8$ and $10 \mathrm{~h}$ on an open laboratory bench. Before measuring stem hydraulic conductivity at each time interval, branches were bagged and left to equilibrate for $1.5-2 \mathrm{~h}$. Ultimately, dehydration of branches should result in the $10 \mathrm{~h}$ measurement revealing a $90-100 \%$ loss in hydraulic conductivity (xylem $90-100 \%$ cavitated). If the required amount of dehydration did not occur, supplementary branches were cut and left for 12-24 h to achieve the desired loss. From each sampled branch, a side branch was cut to measure water potential, using a pressure chamber (Pockman et al. 1995) (PMS instruments, Model 1000, Oregon, USA). The sampled branch was then submerged under water (preventing introduced cavitation) and a stem segment of approximately $10 \mathrm{~cm}$ was cut and edges trimmed with a sharp blade. Previous studies on the same species established that xylem vessels did not exceed $10 \mathrm{~cm}$ in length (Swift et al. 2008; Swift, pers. comm.). Stems were then connected to the tubing apparatus (as described in Sperry et al. 1988) and initial hydraulic conductivity $\left(K_{\mathrm{h}}\right)$ was measured. To obtain maximum conductivity $\left(K_{\max }\right)$, stems were then flushed for $30 \mathrm{~min}$ with 0.1 micrometer filtered, degassed, de-ionised water, at $0.1 \mathrm{MPa}$ (again to prevent introduced cavitation or blockage) and remeasured. Percentage loss in hydraulic conductivity (PLC) for each stem was calculated as:

$$
\mathrm{PLC}=100 \times\left(1-K_{\mathrm{h}} / K_{\max }\right)
$$

Vulnerability curves for each species were fitted with an exponential sigmoidal equation (Pammenter and Van der Willigen 1998):

$$
\operatorname{PLC}=100 /(1+\exp (a(\Psi-b))),
$$

where $\Psi$ is the water potential, PLC is the corresponding loss in hydraulic conductivity and $a$ and $b$ are constants. Water potential where $50 \%$ hydraulic conductivity is lost $\left(\mathrm{P}_{50}\right)$ corresponded to coefficient $b$ in Eq. 2. Significant differences in $\mathrm{P}_{50}$, within and between species and sites, were identified using a test based on the t-distribution, where Bonferroni multiple testing corrections were applied (Statistica Release 8, StatSoft Inc.).

Field xylem water potentials

Stem xylem water potential was measured using a pressure chamber (Pockman et al. 1995) (PMS instruments, Model 1000, Oregon, USA). Measurements were made in summer (December-February), when plants are likely to experience drought stress. Predawn (05h00-05h30) and mid-day (12h00-14h00) measurements were made to obtain maximum (predawn) and minimum (mid-day) water potentials, and were carried out on the same individuals as used for vulnerability curves. Three healthy stems (with leaves) from each individual were cut and measured immediately on site. Three replicates of each treatment were made for each species across all sites. Replicates were conducted on separate days within the month of January 2009. Data were analysed using a factorial ANOVA to determine interactions between sites, species and time of day (pre-dawn or mid-day), followed by a Fisher LSD post-hoc test (Statistica Release 8, StatSoft Inc.).

\section{Foliar carbon isotope analysis}

For the $\delta^{13} \mathrm{C}$ analyses, ten mature (fresh) leaves from each individual (same individuals as used for vulnerability curves and water potentials) were dried at $40^{\circ} \mathrm{C}$ until a constant weight was achieved. Leaves were then crushed into a fine powder and analysed for $\delta^{13} \mathrm{C}$ by combustion in an automated Elemental Analyzer (Carlo-Erba). The carbon isotope ratio was expressed as:

$$
\delta^{13} \mathrm{C}(\%)=\left(\left(R_{\text {sample }}-R_{\text {standard }}\right) / R_{\text {standard }}\right) \times 1,000
$$

where $R_{\text {sample }}$ is the ${ }^{13} \mathrm{C} /{ }^{12} \mathrm{C}$ ratio of the sample, and $R_{\text {standard }}$ the PDB standard.

\section{Results}

Vulnerability of stem xylem to cavitation

Within species, the slopes of vulnerability curves remained relatively constant across sites (Fig. 2), with 

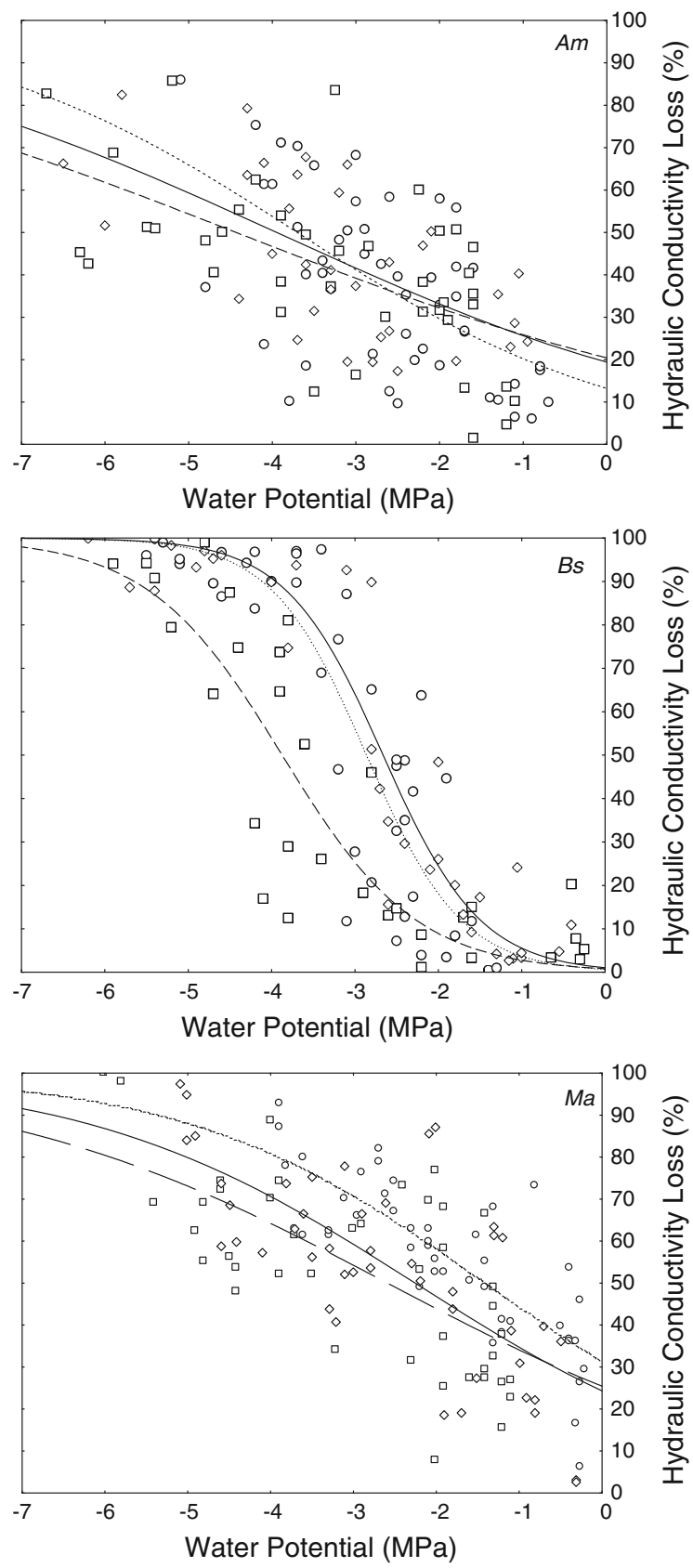

Fig. 2 Vulnerability of stem xylem to cavitation for Acacia mearnsii (Am), Brabejum stellatifolium (Bs) and Metrosideros angustifolia (Ma). Dotted line (and empty circle) is Jonkershoek, dashed line (and empty square) is Bainskloof, and the solid line (and empty diamond) DuToitskloof. Curves were fitted by an exponential sigmoidal function (Pammenter and Van der Willigen 1998). Refer to Table 3 for $R^{2}$ and $P$ values

only the magnitude of $\mathrm{P}_{50}$ values differing (Table 2). At the initiation of measurements $M$. angustifolia and A. mearnsii always had a percentage of their xylem already embolised, and then lost conductivity gradually as water potential declined. In contrast B. stellatifolium started off with near zero percent of its xylem embolised, but at around $-2.5 \mathrm{MPa}$ rapidly started to cavitate. $\mathrm{P}_{50}$ values for $B$. stellatifolium were the lowest at Bainskloof (more negative; $P<0.05$ ). $M$. angustifolia at Jonkershoek had a significantly higher (less negative) $\mathrm{P}_{50}$ than at Bainskloof $(P<0.05)$, but did not differ from DuToitskloof. $M$. angustifolia at Bainskloof and DuToitskloof did not differ significantly from one another. There were no significant differences in $\mathrm{P}_{50}$ values for $A$. mearnsii between all sites. B. stellatifolium reached $100 \%$ loss in conductivity $\left(\mathrm{P}_{100}\right)$ between -5.5 and $-6.5 \mathrm{MPa}$ at Jonkershoek and DuToitskloof, but for Bainskloof $\mathrm{P}_{100}$ was achieved at pressures lower than $-7 \mathrm{MPa}$ (Fig. 2). Across all sites, neither M. angustifolia nor A. mearnsii reached $\mathrm{P}_{100}$ at pressures higher than $-7 \mathrm{MPa}$ (Fig. 2). All species at Bainskloof consistently showed less loss in conductivity at $-7 \mathrm{MPa}$ compared to the other two sites. Overall, A. mearnsii had the lowest absolute $\mathrm{P}_{50}$ values (ranging between -3.70 and $-4.43 \mathrm{MPa}$ ) and $M$. angustifolia the highest (ranging between -1.42 and $-2.59 \mathrm{MPa}$ ).

Within individual sites, consistent patterns were evident in the ranking of species' vulnerability to drought-induced cavitation (Fig. 3, Table 2). At Jonkershoek, $M$. angustifolia had a significantly higher $\mathrm{P}_{50}(P<0.05)$ than either of the other species. This is the same for Bainskloof. At DuToitskloof however, A. mearnsii had a significantly lower $\mathrm{P}_{50}$ value $(P<0.05)$ than either of the other species. Overall, species at Bainskloof showed the lowest $\mathrm{P}_{50}$ values (ranging between -2.59 and $-4.43 \mathrm{MPa}$ ), and species at Jonkershoek the highest (ranging between -1.42 and $-3.70 \mathrm{MPa}$ ).

There was a good relationship $\left(R^{2}\right)$ between water potential and percentage loss in conductivity for both $B$. stellatifolium and $M$. angustifolia, whereas A. mearnsii showed consistently relatively weak correlations (Table 3). However, all of the curves were highly significant.

Field xylem water potentials

At Bainskloof, all species showed significantly lower pre-dawn water potentials compared to the two other sites during the measurement period (dry season) $(P<0.05$; Table 4$)$. Within $B$. stellatifolium and 
Table 2 Mean $\mathrm{P}_{50}$ values across species and streamflow regime

\begin{tabular}{lllr}
\hline Site & Streamflow & Species & $\mathrm{P}_{50}$ \\
\hline Jonkershoek & Low & Brabejum stellatifolium & $-2.86^{\mathrm{bc}}(0.09)$ \\
& & Metrosideros angustifolia $^{\mathrm{d}}$ & $-1.42^{\mathrm{d}}(0.14)$ \\
& & Acacia mearnsii $^{\mathrm{a}}$ & $-3.70^{\mathrm{ab}}(0.27)$ \\
Bainskloof & Intermediate & Brabejum stellatifolium & $-3.87^{\mathrm{a}}(0.15)$ \\
& & Metrosideros angustifolia & $-2.59^{\mathrm{bc}}(0.26)$ \\
& & Acacia mearnsii & $-4.43^{\mathrm{a}}(0.43)$ \\
DuToitskloof & High & Brabejum stellatifolium & $-2.66^{\mathrm{c}}(0.09)$ \\
& & Metrosideros angustifolia & $-2.26^{\mathrm{cd}}(0.22)$ \\
& & Acacia mearnsii & $-3.95^{\mathrm{ab}}(0.35)$ \\
\hline
\end{tabular}

All values are in MPa. Standard errors are given in parentheses. A test based on the t-distribution was used to compare estimates of the different streamflow treatments. Bonferroni multiple testing corrections were applied. Within and between sites, means with different superscripts differ significantly $(P<0.05)$

M. angustifolia, no significant differences existed in pre-dawn water potentials at either Jonkershoek or DuToitskloof. In contrast, pre-dawn water potentials for A. mearnsii at Jonkershoek were significantly higher than at DuToitskloof $(P<0.05)$. Comparisons between species within individual sites revealed that species at Jonkershoek showed no significant difference in their pre-dawn water potential. At DuToitskloof, only A. mearnsii had a significantly lower predawn water potential. At Bainskloof all three species differed significantly in their pre-dawn water potentials $(P<0.05)$, with $B$. stellatifolium having the highest water potential $(-0.66 \mathrm{MPa})$, and $A$. mearnsii the lowest $(-1.50 \mathrm{MPa})$.

Within species, across all sites, B. stellatifolium showed no significant difference in mid-day water potential (Table 4). M. angustifolia at Jonkershoek did not differ significantly from Bainskloof or DuToitskloof, but had a significantly lower water potential at Bainskloof than at DuToitskloof. For A. mearnsii, only Bainskloof showed significantly lower mid-day water potentials $(P<0.05)$. Comparisons between species, within and across sites, revealed that B. stellatifolium was consistently less water-stressed at mid-day than M. angustifolia or A. mearnsii, which did not differ from one another.

Foliar $\delta^{13} \mathrm{C}$

All species showed their lowest $\delta^{13} \mathrm{C}$ at DuToitskloof, the high streamflow site (Table 5). M. angustifolia at Jonkershoek and DuToitskloof had a significantly higher $\delta^{13} \mathrm{C}$ value $(P<0.05)$ compared to A. mearnsii and B. stellatifolium at these sites. The latter two species showed no significant difference when compared with each another. At Bainskloof, B. stellatifolium and $A$. mearnsii again did not differ significantly, but here, $M$. angustifolia had a significantly higher $\delta^{13} \mathrm{C}$ value than $B$. stellatifolium, but not $A$. mearnsii. Overall, $M$. angustifolia showed the highest $\delta^{13} \mathrm{C}$ values.

\section{Discussion}

It is well known that woody plants display speciesspecific structural and physiological adaptations to prolonged drought periods (Beikircher and Mayr 2009). In our study, consistency in the shapes of vulnerability curves of the three selected species across all sites (where only the magnitude of measured $\mathrm{P}_{50}$ values differed), illustrates that species-specific hydraulic architecture remained relatively intact across sites that differ in water availability. However, the significant changes in magnitude of $\mathrm{P}_{50}$ within a species represented in situ adaptation to different degrees of environmental pressure. Swift et al. (2008) found similar differences in $\mathrm{P}_{50}$ among different tributaries of the same catchment. Thus, between species, there were diverse responses to hydrological drought (D' Odorico and Porporato 2006), but within species consistent trends were observed. Intra-specific differences between populations confirm that vulnerability to cavitation might either be a plastic response to environment (Pockman and Sperry 2000), or the effect of genetic differences (Kolb and Sperry 1999). 

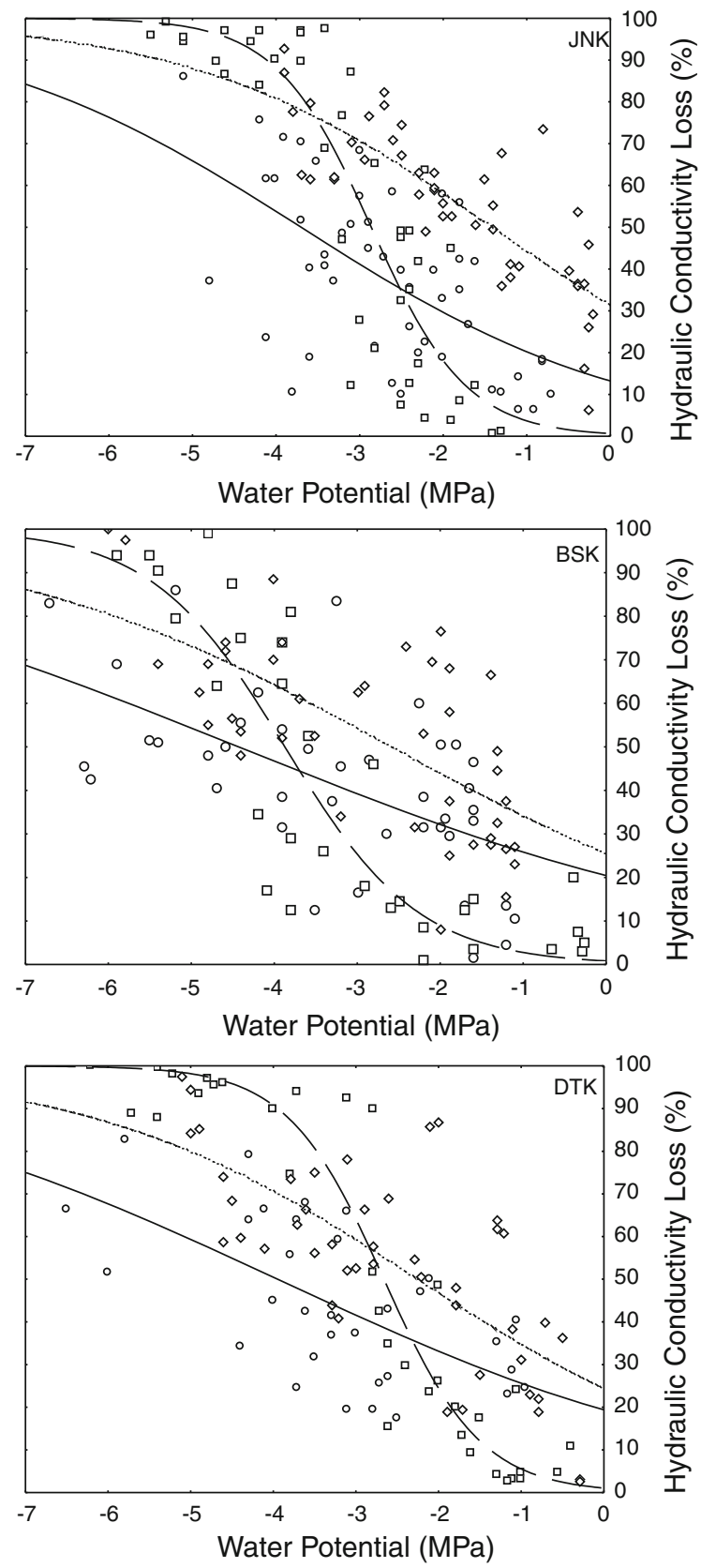

Fig. 3 Vulnerability of stem xylem to cavitation for the studied species at three sites representing low flow, viz Jonkershoek (JNK), intermediate flow, viz Bainskloof (BSK), and high flow, viz DuToitskloof (DTK), streamflow regimes. At each site, the dotted line (and empty diamond) is Metrosideros angustifolia, dashed line (and empty square) is Brabejum stellatifolium, and the solid line (and empty circle) Acacia mearnsii. Curves were fitted by an exponential sigmoid function (Pammenter and Van der Willigen 1998). Refer to Table 3 for $R^{2}$ and $P$ values
However, more research is needed in this regard (see also Hacke and Sperry 2001).

Of the native species studied, $M$. angustifolia had higher $\mathrm{P}_{50}$ values than B. stellatifolium at both the low and intermediate flow sites, indicating that the former may be less drought-tolerant (Cochard et al. 2008). However, at the high flow site there was no clear difference in vulnerability to cavitation between the native species. In general, the invasive alien A. mearnsii showed evidence of being more droughttolerant across all sites. However, only at DuToitskloof did it show significantly greater drought-tolerance than both native species, as B. stellatifolium did not differ significantly from the invasive species at the other sites. In contrast, A. mearnsii always showed higher drought-tolerance than $M$. angustifolia within each site. These results indicate that for the selected native species, $B$. stellatifolium is the most droughttolerant and thus better adapted to drier conditions than M. angustifolia. This confirms findings of Swift et al. (2008), who worked on the Eerste River and adjacent river catchments. The threat of persistence of A. mearnsii as an invader in drought prone Mediterranean climates (dry summers) becomes apparent as it clearly exhibited lower $\mathrm{P}_{50}$ values at certain sites and in contrast to some native species. Field xylem water potentials further support the contention that the invasive A. mearnsii has a significant advantage over some native species under drier conditions.

Minimum field water potential $\left(\Psi_{\min }\right)$ is an important measure of plant water status, as it represents the minimum moisture status plants must tolerate to remain physiologically active (Bhaskar and Ackerly 2006). Our results indicated, as with vulnerability to cavitation, that within and between species and sites there were significant differences in water potentials at pre-dawn and mid-day. For Mediterranean-type ecosystems, Bhaskar et al. (2007) found an evolutionary link between minimum water potentials (mid-day) and xylem structure, with plants experiencing low water potentials having more drought-tolerant xylem. However, our data revealed that the least drought-tolerant species, $M$. angustifolia shared the same water potential in response to water-stress conditions as the very drought-tolerant $A$. mearnsii which had a greater safety margin against water potentials that would cause $50 \%$ of its xylem to cavitate $\left(\mathrm{P}_{50}\right)$ and so induce runaway cavitation. So, even though $A$. mearnsii had low pre-dawn and mid-day water potentials, it 
Table $3 R^{2}$ values and probability (P) of fitted vulnerability to cavitation curves for species across all sites

\begin{tabular}{lllll}
\hline Site & Species & Equation & $R^{2}$ & $P$ \\
\hline Jonkershoek & Brabejum stellatifolium & $y=100 /\left(1+\exp \left((1.75375)^{*}(x-(-2.8606))\right)\right)$ & 0.76 & $<0.001$ \\
& Metrosideros angustifolia & $y=100 /\left(1+\exp \left((.555544)^{*}(x-(-1.4174))\right)\right)$ & 0.65 & $<0.001$ \\
& Acacia mearnsii & $y=100 /\left(1+\exp \left((.508276)^{*}(x-(-3.7012))\right)\right)$ & 0.38 & $<0.001$ \\
Bainskloof & Brabejum stellatifolium & $y=100 /\left(1+\exp \left((1.23879)^{*}(x-(-3.8726))\right)\right)$ & 0.76 & $<0.001$ \\
& Metrosideros angustifolia & $y=100 /\left(1+\exp \left((.414685)^{*}(x-(-2.5904))\right)\right)$ & 0.46 & $<0.001$ \\
& Acacia mearnsii & $y=100 /\left(1+\exp \left((.306903)^{*}(x-(-4.4311))\right)\right)$ & 0.35 & $<0.001$ \\
DuToitskloof & Brabejum stellatifolium & $y=100 /\left(1+\exp \left((1.7069)^{*}(x-(-2.6617))\right)\right)$ & 0.90 & $<0.001$ \\
& Metrosideros angustifolia & $y=100 /\left(1+\exp \left((.50287)^{*}(x-(-2.256))\right)\right)$ & 0.53 & $<0.001$ \\
& Acacia mearnsii & $y=100 /\left(1+\exp \left((.360492)^{*}(x-(-3.9484))\right)\right)$ & 0.38 & $<0.001$ \\
\hline
\end{tabular}

Table 4 Mean values for summer Pre-Dawn ( $\left.\Psi_{\max }\right)$ and Mid-Day $\left(\Psi_{\min }\right)$ water potentials across species and sites (dry season)

\begin{tabular}{lllll}
\hline Time of day & Species & Jonkershoek & Bainskloof & DuToitskloof \\
\hline Pre-dawn & Brabejum stellatifolium & $-0.27^{\mathrm{a}}(0.02)$ & $-0.66^{\mathrm{cde}}(0.08)$ & $-0.32^{\mathrm{a}}(0.02)$ \\
& Metrosideros angustifolia & $-0.36^{\mathrm{a}}(0.06)$ & $-1.10^{\mathrm{b}}(0.11)$ & $-0.43^{\mathrm{ae}}(0.05)$ \\
& Acacia mearnsii & $-0.52^{\mathrm{ad}}(0.02)$ & $-1.50^{\mathrm{f}}(0.14)$ & $-1.01^{\mathrm{b}}(0.09)$ \\
Mid-day & Brabejum stellatifolium & $-1.91^{\mathrm{a}}(0.08)$ & $-1.95^{\mathrm{a}}(0.06)$ & $-1.89^{\mathrm{a}}(0.07)$ \\
& Metrosideros angustifolia & $-2.65^{\mathrm{bd}}(0.12)$ & $-2.85^{\mathrm{de}}(0.10)$ & $-2.52^{\mathrm{b}}(0.07)$ \\
& Acacia mearnsii & $-2.60^{\mathrm{bd}}(0.07)$ & $-2.96^{\mathrm{ce}}(0.07)$ & $-2.65^{\mathrm{bd}}(0.05)$ \\
\hline
\end{tabular}

All values are in MPa. Standard errors are given in parentheses. A factorial ANOVA was used to compare species and sites, with means separated using Fisher's LSD test. Within and between sites, means with different superscripts differ significantly $(P<0.05)$. $n=5$

Table $5 \delta^{13} \mathrm{C}$ as indicator of water use efficiency (WUE)

\begin{tabular}{lll}
\hline Site & Species & $\delta^{13} \mathrm{C}(\%)$ \\
\hline Jonkershoek & Brabejum stellatifolium & $-25.3^{\mathrm{a}}(0.52)$ \\
& Metrosideros angustifolia & $-23.6^{\mathrm{b}}(0.41)$ \\
& Acacia mearnsii & $-25.4^{\mathrm{a}}(0.26)$ \\
Bainskloof & Brabejum stellatifolium & $-24.8^{\mathrm{ad}}(0.19)$ \\
& Metrosideros angustifolia & $-22.7^{\mathrm{b}}(0.59)$ \\
& Acacia mearnsii & $-23.8^{\mathrm{bde}}(0.32)$ \\
DuToitskloof & Brabejum stellatifolium & $-26.8^{\mathrm{c}}(0.46)$ \\
& Metrosideros angustifolia & $-25.0^{\mathrm{ae}}(0.48)$ \\
& Acacia mearnsii & $-27.0^{\mathrm{c}}(0.41)$ \\
\hline
\end{tabular}

A factorial ANOVA was used to determine species and site interactions. Within sites and species, WUE differ significantly $(P<0.001$ respectively); there were no significant interactions between sites and species. Means were separated using Fisher's LSD test. Within and between sites, means with different superscripts differ significantly $(P<0.05)$. Standard error is given in parentheses

balances this against having high drought-tolerance because of its greater safety margin against cavitation. B. stellatifolium was as drought-tolerant as A. mearnsii in at least two sites, and experienced significantly higher minimum water potentials overall. This species also never reached water potentials low enough to reach its $\mathrm{P}_{50}$ level, and thus operated at a greater safety margin against runaway cavitation. Moreover, $B$. stellatifolium showed no significant difference in $\Psi_{\text {min }}$ between sites. It is known that the major influence on $\Psi_{\text {min }}$ measurements in plants is relative access to soil water (Ackerly 2004; Wikberg and Ögren 2004); one could thus deduce that B. stellatifolium has more effective access to groundwater in diverse environments, whereas other species do not. This species should persist in future drier conditions, and shows promise for use in post-clearing restoration.

In contrast, $M$. angustifolia functioned very close to, and often beyond its $\mathrm{P}_{50}$ threshold, showing the same trend as in a previous riparian study (Swift et al. 2008). The question is then-what other strategies might $M$. angustifolia use to tolerate or avoid drought, if any? It is possible $M$. angustifolia closes its stomata during low mid-day water potentials (not measured in this study), as was found for species that operate near 
their hydraulic limit or $\mathrm{P}_{50}$ (Linton et al. 1998; Wikberg and Ögren 2004). Indirect evidence for this strategy was obtained from delta ${ }^{13} \mathrm{C}$ isotope $\left(\delta^{13} \mathrm{C}\right)$ results.

Delta ${ }^{13} \mathrm{C}$ is seen as a biological expression of environmental conditions and provides an integrated measure to predict availability of water to plants (Stewart et al. 1995). Response to environmental conditions such as soil moisture is also speciesspecific (Ponton et al. 2001; Akhter et al. 2005). Akhter et al. (2005) showed that plants with a high WUE have the ability to maintain water uptake during drought by being hydraulically efficient through their conservative water use. This enables species to persist in a water-limited situation and is a form of drought adaptation. At two sites $M$. angustifolia exhibited significantly higher $\delta^{13} \mathrm{C}$ values than the other study species, and therefore it adheres to a conservative water strategy. The indication is that although M. angustifolia functions close to its $\mathrm{P}_{50}$ value, and from this perspective appeared to be the least droughttolerant of the natives, it might still persist in certain future drier conditions due to a different water use strategy, perhaps by closing its stomata (isohydry) for some time during the day. However, this may induce mortality through carbon starvation as reserves of carbon are exhausted under extended drought conditions (McDowell et al. 2008). Another strategy to achieve drought-tolerance within species is where xylem cavitation proceeds, but not through the whole plant (Rood et al. 2000). This is also known as hydraulic segmentation (Tyree et al. 1993), vulnerability segmentation (Tsuda and Tyree 2007) or branch sacrifice (Rood et al. 2000). Swift et al. (2008) suggested that species that operate near their hydraulic limit, such as $M$. angustifolia might employ branch sacrifice as an adaptation against drought conditions, as anecdotal field observations suggest. In contrast, A. mearnsii had low isotopic values, which confirms that it is a profligate user of water where it has access to large amounts, as suggested by Dye et al. (2001).

There is strong evidence that small changes in environmental conditions induce selection of improved plant adaptation strategies with regards to safe and efficient hydraulic transport (Ponton et al. 2001). A comparison of results over various streamflow regimes yielded interesting data, which agree with the ecological strategies of the species described above. B. stellatifolium and $M$. angustifolia had their lowest $\mathrm{P}_{50}$ values at the intermediate flow site, Bainskloof, as opposed to the low flow site, Jonkershoek, suggesting that these species at Bainskloof are more drought-tolerant than at Jonkershoek. Jonkershoek and DuToitskloof, respectively the lowest and highest flow sites, also did not show apparent differences between species. Water potential $(\Psi)$ data also suggested Bainskloof as the site where some species experienced significantly more stressed conditions. Additionally, Bainskloof was also the site where species had high WUE, again indicating it as a more drought-stressed environment, despite its intermediate stream flow regime. A similar result was found with Vitis vinefera where some sites were significantly more water-use efficient than others, promoted by a deficit in water availability (De Souza et al. 2005).

Our results thus challenge the hypothesis that species will be more drought-tolerant at lower streamflow sites, as suggested by Swift et al. (2008) as well as other studies on riparian plants and their physiology (e.g. Willms et al. 1998; Rood et al. 2003). Riparian environments are typically highly heterogeneous in space (Naiman et al. 2005). Higher run-off does not necessarily ensure more plant water availability, and is therefore not an accurate predictor of in situ species drought-tolerance. Microsite or other factors such as site-specific geomorphology and microclimate (for example vapour pressure deficit) may play a more prominent role in selection towards greater droughttolerance (Hupp and Osterkamp 1996). All three sites had highly permeable bed characteristics, though at Bainskloof the sample trees were found away from the water's edge, and grew in positions elevated above the stream, which may indicate less available groundwater, in contrast to the sample trees at Jonkershoek and at DuToitskloof. In addition, at Bainskloof the valley is more incised than the two other valleys, and the sampling sites are also located at higher altitudes (Mountain Stream Transitional as opposed to Foothills) (see Table 1) with lower potential for depositional processes, which may suggest lower groundwater reserves.

\section{Conclusions}

Vulnerability to cavitation is seen as the most important parameter in determining drought-tolerance in a tree (Cruiziat et al. 2002). Considerable variation 
existed within and between species in their vulnerability to stem cavitation as measured by vulnerability curves, an indication of species-specific responses to withstand drought stress (different life-history strategies), and the variation within species under different environmental conditions (Cruiziat et al. 2002; Maherali et al. 2004). The invasive A. mearnsii was shown to be highly drought-tolerant, able to withstand low minimum water potentials and able to utilize more water, so it will be able to persist in future drier conditions, and must therefore remain a top priority for control. Fortunately, the co-occurring native, B. stellatifolium is also likely to persist under future drier conditions. It is well suited for restoration after clearing of invasions, which confirms results found by Swift et al. (2008), though the latter study was carried out over a much smaller geographic range. These consistent results between species and over sites strengthen the argument that this mechanistic approach to distinguish site-level drought-tolerance between plants and their drought-tolerance at a specific site, is a practical technique, with application in understanding future geographic distributions of species under climate change and their potential for use in restoration research. Vulnerability to cavitation and mid-day water potentials are also strongly linked for A. mearnsii, and therefore minimum water potentials are a valuable tool to predict its plant functional strategy with regards to drought (Bhaskar and Ackerly 2006). More research in understanding the mechanism of plant survival and mortality under different drought intensities and durations will be key in predicting species distribution and range for future drier conditions (McDowell et al. 2008). Lastly, streamflow per $s e$ is not robust enough to use as a screening tool when predicting drought-tolerance of species at a specific site as there was no relationship between droughttolerance and river flows.

The management implications of this study are that sites could now be given top priority in clearing, e.g. DuToitskloof in this case, as this site has shown less drought-tolerance of both native species. We thus have another tool to assess the impact of uncontrolled invasion on native species in riparian zones, especially important when taking into consideration the projected rapid onset of drier conditions predicted for some regions (New 2002). However, specific microsite conditions are also a major consideration in prioritising sites.
Acknowledgments We thank the Working for Water programme and the Centre for Invasion Biology at Stellenbosch University for funding, Cape Nature for a research permit (no. AAA008-00022-0028), and the Department of Water Affairs and Council for Scientific and Industrial Research for streamflow data. Also to all private landowners for access to their properties, and to Cheryl Swift, Dave le Maitre and two anonymous reviewers for useful comments on an earlier version of this manuscript, and Martin Kidd for guidance with statistical analysis.

\section{References}

Ackerly DD (2004) Functional strategies of chaparral shrubs in relation to seasonal water deficit and disturbance. Ecol Monogr 74:25-44

Akhter J, Mahmood K, Tasneem MA, Malik KA, Naqvi MH, Hussain F, Serraj R (2005) Water-use efficiency and carbon isotope discrimination of Acacia ampliceps and Eucalyptus camaldulensis at different soil moisture regimes under semi-arid conditions. Biol Plantarum 49:269-272

Beikircher B, Mayr S (2009) Intraspecific differences in drought-tolerance and acclimation in hydraulics of Ligustrum vulgare and Viburnum lantana. Tree Physiol 29:765-775

Bhaskar R, Ackerly DD (2006) Ecological relevance of minimum seasonal water potentials. Physiol Plant 127:353-359

Bhaskar R, Valiente-Banuet A, Ackerly DD (2007) Evolution of hydraulic traits in closely related species pairs from mediterranean and nonmediterranean environments of North America. New Phytol 176:718-726

Bosch JM, Hewlett JD (1982) A review of catchment experiments to determine the effect of vegetation changes on water yield and evapotranspiration. J Hydrol 55:3-23

Boucher C, Tlale S (1999). Riparian and instream vegetation study. Unpublished report prepared for Lesotho highlands development authority. Lesotho highlands water project, Metsi consultants, Maseru. Report 64814

Coates-Palgrave K (2002) Trees of Southern Africa. Struik Publishers, Cape Town

Cochard H, Barigah ST, Kleinhentz M, Eshel A (2008) Is xylem cavitation-resistance a relevant criterion for screening drought resistance among Prunus species? J Plant Physiol 165:976-982

Cruiziat P, Cochard H, Améglio T (2002) Hydraulic architecture of trees: main concepts and results. Ann For Sci 59:723-752

D' Odorico P, Porporato A (2006) Dryland ecohydrology. Springer, The Netherlands

Davies B, Day J (1998) Vanishing waters. University of Cape Town Press, Cape Town

Dawson TE, Ehleringer JR (1991) Streamside trees that do not use stream water: evidence from hydrogen isotope ratios. Nature 350:335-337

De Souza CR, Maroco JP, dos Santos TP, Rodrigues ML, Lopes CM, Pereira JS, Chaves MM (2005) Impact of deficit irrigation on water use efficiency and carbon isotope composition $(\delta 13 \mathrm{C})$ of field-grown grapevines under Mediterranean climate. J Exp Bot 56:2163-2172 
Dye P, Jarmain C (2004) Water use by black wattle (Acacia mearnsii): implications for the link between removal of invading trees and catchment streamflow response. S Afr J Sci 100:40-44

Dye P, Moses G, Vilakazi P, Ndlela R, Royappen M (2001) Comparative water use of water thickets and indigenous plant communities at riparian sites in the Western Cape and KwaZulu-Natal. Water SA 27:529-538

Farquhar GD, O' Leary MH, Berry JA (1982) On the relationship between carbon isotope discrimination and the intercellular carbon dioxide concentration in leaves. Aust $\mathbf{J}$ Plant Physiol 9:121-137

Galatowitsch S, Richardson DM (2005) Riparian scrub recovery after clearing of invasive alien trees in headwater streams of the Western Cape, South Africa. Biol Conserv 122:509521

Hacke UG, Sperry JS (2001) Functional and ecological xylem anatomy. Perspect Plant Ecol Evol Syst 4:97-115

Hacke UG, Sperry JS, Pittermann J (2000) Drought experience and cavitation-resistance in six shrubs from the Great Basin, Utah. Basic Appl Ecol 1:31-41

Hupp CR, Osterkamp WR (1996) Riparian vegetation and fluvial geomorphic processes. Geomorphology 14:277-295

King JM, Schael DM (2001). Assessing the ecological relevance of a spatially-nested geomorphological hierarchy for river management. WRC Report 754/1/01

Kolb KJ, Sperry JS (1999) Differences in drought adaptation between subspecies of Sagebrush (Artemisia tridentata). Ecology 80:2373-2384

Kraaij T, Cramer MD (1999) Do the gas exchange characteristics of alien Acacias enable them to successfully invade the fynbos? S Afr J Bot 65:232-238

Lambers H, Pons TL, Chapin FS III (1998) Plant physiological ecology. Springer, New York

Le Maitre DC, Van Wilgen BW, Chapman RA, McKelly DH (1996) Invasive plants and water resources in the Western Cape Province, South Africa: modelling the consequences of a lack of management. J Appl Ecol 33:161-172

Le Maitre DC, Van Wilgen BW, Gelderblom CM, Bailey C, Chapman RA, Nel JA (2002) Invasive alien trees and water resources in South Africa: case studies of the costs and benefits of management. For Ecol Manag 160:143-159

Linton MJ, Sperry JS, Williams DG (1998) Limits to water transport in Juniperus osteosperma and Pinus edulis: implications for drought-tolerance and regulation of transpiration. Funct Ecol 12:906-911

Maherali H, Pockman WT, Jackson RB (2004) Adaptive variation in the vulnerability of woody plants to xylem cavitation. Ecology 85:2184-2199

Maherali H, Moura CF, Caldeira MC, Willson CJ, Jackson RB (2006) Functional coordination between leaf gas exchange and vulnerability to xylem cavitation in temperate forest trees. Plant Cell Environ 29:571-583

Martínez-Vilalta J, Piñol J, Beven K (2002) A hydraulic model to predict drought-induced mortality in woody plants: an application to climate change in the Mediterranean. Ecol Model 155:127-147

McDowell N, Pockman WT, Allen CD, Breshears DD, Cobb N, Kolb T, Plaut J, Sperry J, West A, Williams DG, Yepez EA (2008) Mechanisms of plant survival and mortality during drought: why do some plants survive while others succumb to drought? New Phytol 178:719-739

Meadows ME (2006) Global change in South Africa. Geogr Res 44:135-145

Meinzer FC (2003) Functional convergence in plant responses to the environment. Oecologia 134:1-11

Mencuccini M, Comstock J (1997) Vulnerability to cavitation in populations of two desert species, Hymenoclea salsola and Ambrosia dumosa, from different climatic regions. J Exp Bot 48:1323-1334

Morris TL, Esler KJ, Barger NN, Jacobs SM, Cramer MD (2011) Ecophysiological traits enabling competitive invasive success of Australian Acacias. Divers Distrib 17: 898-910

Naiman RJ, Decamps H (1997) The ecology of interfacesriparian zones. Annu Rev Ecol Syst 28:621-658

Naiman RJ, Decamps H, McClain ME (2005) Riparia: ecology, conservation, and management of streamside communities. Elsevier Academic Press, USA

New M (2002) Climate change and water resources in the southwestern Cape, South Africa. S Afr J Sci 98:1-8

Pammenter NW, Van der Willigen C (1998) A mathematical and statistical analysis of the curves illustrating vulnerability of xylem to cavitation. Tree Physiol 18:589-593

Pockman WT, Sperry JS (2000) Vulnerability to xylem cavitation and the distribution of Sonoran Desert vegetation. Am J Bot 87:1287-1299

Pockman WT, Sperry JS, O'Leary JW (1995) Sustained and significant negative water pressure in xylem. Nature 378:715-716

Ponton S, Dupouey JL, Bréda N, Feuillat F, Bodénès C, Dreyer E (2001) Carbon isotope discrimination and wood anatomy variations in mixed stands of Quercus robur and Quercus petraea. Plant Cell Environ 24:861-868

Pratt RB, Black RA (2006) Do invasive trees have a hydraulic advantage over native trees? Biol Invasions 8:1331-1341

Prins N, Holmes PM, Richardson DM (2004) A reference framework for the restoration of riparian vegetation in the Western Cape, South Africa, degraded by invasive Australian Acacias. S Afr J Bot 70:767-776

Reinecke MK, King JM (2007) The nature and invasion of riparian vegetation zones in the southwestern Cape. WRC Report 1407/1/07

Richardson DM, van Wilgen BW (2004) Invasive alien plants in South Africa: how well do we understand the ecological impacts? S Afr J Sci 100:45-52

Rood SB, Patiño S, Coombs K, Tyree MT (2000) Branch sacrifice: cavitation-associated drought adaptation of riparian cottonwoods. Trees Struct Funct 14:248-257

Rood SB, Braatne JH, Hughes FMR (2003) Ecophysiology of riparian cottonwoods: stream flow dependency, water relations and restoration. Tree Physiol 23:1113-1124

Schulze R, Meigh J, Horan M (2001) Present and potential future vulnerability of eastern and southern Africa's hydrology and water resources. S Afr J Sci 97:150-160

Scott DF, Le Maitre DC, Fairbanks DHK (1998) Forestry and streamflow reductions in South Africa: a reference system for assessing extent and distribution. Water SA 24:187-199

Seibt U, Rajabi A, Griffiths H, Berry J (2008) Carbon isotopes and water use efficiency: sense and sensitivity. Oecologia 155:441-454 
Sieben EJJ, Reinecke MK (2008) Description of reference conditions for restoration projects of riparian vegetation from the species-rich fynbos biome. S Afr J Bot 74(3): $401-411$

Sparks JB, Black RA (1999) Regulation of water loss in populations of Populus trichocarpa: the role of stomatal control in preventing cavitation. Tree Physiol 19:453-459

Sperry JS, Donnelly JR, Tyree MT (1988) A method for measuring hydraulic conductivity and embolism in xylem. Plant Cell Environ 11:35-40

Stewart GR, Turnbull MH, Schmidt S, Erskine PD (1995) ${ }^{13} \mathrm{C}$ Natural abundance in plant communities along a rainfall gradient: a biological integrator of water availability. Aust J Plant Physiol 22:51-55

Steynor AC, Hewitson BC, Tadross MA (2009) Projected future runoff of the Breede River under climate change. Water SA 35(4):433-440

Swift CC, Jacobs SM, Esler KJ (2008) Drought induced xylem embolism in four riparian trees from the Western Cape Province: insights and implications for planning and evaluation of restoration. S Afr J Bot 74:508-516

Tsuda M, Tyree MT (2007) Whole-plant hydraulic resistance and vulnerability segmentation in Acer saccharinum. Tree Physiol 17:351-357
Tyree MT, Sperry JS (1988) Do woody plants operate near the point of catastrophic xylem dysfunction caused by dynamic water stress?: answers from a Model. Plant Physiol 88:574-580

Tyree MT, Cochard H, Cruiziat P, Sinclair B, Ameglio T (1993) Drought-induced leaf shedding in walnut: evidence for vulnerability segmentation. Plant Cell Environ 16:879-882

Walmsley RD, Walmsley JJ, Mzuri Consultants, Silberbauer M, Department of affairs and forestry (1999) Freshwater systems and resources. National state of the environment report, Department of Environmental Affairs and Tourism, Republic of South Africa

Wheeler JK, Sperry JS, Hacke UG, Hoang N (2005) Inter-vessel pitting and cavitation in woody Rosaceae and other vesselled plants: a basis for a safety versus efficiency trade-off in xylem transport. Plant Cell Environ 28:800-812

Wikberg J, Ögren E (2004) Interrelationships between water use and growth traits in the biomass-producing willows. Trees 18:70-76

Willms J, Rood SB, Willms W, Tyree M (1998) Branch growth of riparian cottonwoods: a hydrologically sensitive dendrochronological tool. Trees 12:215-223 